\title{
Perkawinan Dalam Terang Kitab Suci
}

Oleh: Yohanes Fransiskus Siku Jata

\begin{abstract}
Abstrak:
Tulisan ini bermaksud memperkenalkan secara singkat Perkawinan Katolik dalam terang Kitab Suci. Menurut Kitab Suci, perkawinan dibentuk oleh Allah. Karena perkawinan dibentuk oleh Allah, maka perkawinan disebut suci, karena Allah sendiri adalah suci. Pemahaman tentang perkawinan sebagai hasil ciptaan Allah ini memiliki hubungan dengan penciptaan dunia dan manusia. Atas dasar pikiran ini maka perkawinan merupakan bagian dari maksud Allah menciptakan dunia dan manusia.

Sebagai lembaga yang suci, perkawinan merupakan simbol perjanjian kesetiaan antara Tuhan dan Israel umatNya. Tuhan adalah Allah yang setia, sedangkan Israel adalah umat yang tidak setia. Sebagai Allah yang setia, Tuhan selalu memanggil Israel untuk setia seperti Dia. Tuhan tidak menghendaki Israel umatNya berpisah dari Dia. Kesetiaan terhadap janji Allah itu harus diwujudkan dengan tetap bersatu dengan Tuhan, bukan sebaliknya memisahkan diri dari Dia, lalu mempersatukan diri dengan dewa-dewi yang bukan Tuhan; bukan menceraikan diri dari pasangan suami istri sendiri, lalu menghampiri dan mengawini wanita dan pria lain. Karena itu perkawinan yang merupakan simbol persekutuan antara Tuhan dan umatNya ini bersifat tidak terceraikan. Dan perceraian merupakan bukti ketidaksetiaan manusia terhadap janji Allah. Perkawinan sebagai hasil ciptaan dan bentukan Allah menuntut keterlibatan total dari pihak manusia. Perkawinan adalah karya agung Allah yang menuntut partisipasi kreatif manusia demi mencapai cita-cita kebahagiaan dan keselamatan sesuai maksud Allah Pencipta.
\end{abstract}

Kata-kata Kunci: Allah, suci, perjanjian, kesetiaan, partisipasi kreatif manusia.

\section{Pendahuluan}

$\mathrm{B}$ eberapa waktu yang lalu penulis didatangi oleh seorang calon katekis dan bertanya perihal: "Seorang wanita yang sudah tidak perawan lagi, dan dia berkehendak menikah dengan seorang pria lain". Pertanyaannya ialah ini: apakah perkawinan yang akan dijalani oleh wanita itu adalah perkawinan suci.

Sesungguhnya pertanyaan yang dialamatkan kepada penulis ini adalah pertanyaan yang sebelumnya diajukan kepadanya saat dia menjalani masa pastoralnya di tengah umat di sebuah paroki. Berbekalkan pengetahuan yang telah diperolehnya, calon katekis itu berusaha untuk menjelaskan kepada mereka, namun mereka tidak puas dengan jawabannya. Di hadapannya mereka malah mengatakan bahwa perkawinan itu dikatakan suci kalau dijalani oleh orang yang masih perawan.

Bagi penulis pertanyaan ini menarik, karena dapat melahirkan pelbagai macam tanggapan. Pertama: Kalau ada perkawinan suci untuk orang yang masih perawan, pertanyaannya adalah apakah ada perkawinan yang tidak suci. Kedua: Bisa saja orang berpikir, suci atau tidak sucinya sebuah perkawinan ada hubungannnya dengan masa lalu calon mempelai. Tetapi seandainya orang itu punya masa lalu yang hitam, lalu jauh-jauh hari sebelum perkawinannya dia telah bertobat dan berlaku baik (dan bahkan menjadi teladan bagi yang lain); atau dengan kata lain dia bukan seperti yang dulu lagi, apakah dia tetap dipandang sebagai orang yang jahat atau tidak suci? 
Ketiga: Apakah kesucian sebuah perkawinan tergantung pada orang yang akan menjalani perkawinan, atau pada Tuhan pembentuk dan pencipta perkawinan. ${ }^{1}$ Tulisan ini tidak bermaksud mempertanggungjawabkan pertanyaan: apakah perkawinan yang akan dijalani oleh orang yang sudah tidak perawan, perkawinan itu suci atau tidak suci. Pertanyaan tersebut mendorong penulis mengangkat tema Perkawinan Dalam terang Kitab Suci. Hal ini dilandasi oleh pemikiran bahwa akar atau dasar sehingga perkawinan katolik disebut suci justru terkandung di dalam Kitab Suci.

Tetapi apa yang dimaksudkan dengan Perkawinan Menurut Kitab Suci? Ini adalah pertanyaan yang tidak mudah dijawab, karena tidak ada teks Kitab Suci yang secara eksplisit menggambarkan apa sesungguhnya perkawinan itu. Dalam Perjanjian Lama dan Perjanjian Baru tidak ada ajaran yang sistematis tentang perkawinan. Yang ada hanyalah penggalanpenggalan kisah yang menunjukkan bagaimana kepercayaan dan praktek orang-orang zaman Perjanjian Lama (Hibrani) sehubungan dengan perkawinan. Dan kepercayaan serta praktek masyarakat Perjanjian Lama itu turut mempengaruhi kepercayaan dan praktek orang-orang Kristen Purba (gereja perdana). ${ }^{2}$ Karena itu berikut ini akan dipaparkan kepercayaan dan praktek masyarakat Perjanjian Lama dan Perjanjian Baru sehubungan dengan perkawinan sejauh termuat di dalam Kitab Suci.

\section{Tuhan Pencipta Perkawinan}

\subsection{Penciptaan Manusia, Pria dan Wanita (Kej. 1:26-31)}

Kitab Kejadian bab 1 berkisah tentang penciptaan dunia dan segala isinya (ay. 1-25), serta tentang penciptaan manusia (ay. 26-31). Penulis memperlihatkan bahwa Tuhan adalah pencipta, dan Tuhan menciptakan dengan bersabda. Pertama-tama Tuhan menciptakan dunia dan segala isinya, yakni terang, cakrawala, bumi dan tumbuh-tumbuhan, penerang-penerang di langit, burung-burung dan ikan, serta binatang-binatang darat. Setelah semua itu diciptakanNya, Tuhan lalu menciptakan manusia. Dengan menciptakan manusia dan menempatkannya pada bagian akhir, penulis ingin menegaskan bahwa manusia adalah puncak dari seluruh ciptaan. Sebagai puncak dari semua ciptaan, Tuhan memberikan manusia tugas untuk mengatur dan mengelola isi ciptaan. Dan kelebihan manusia sebagai puncak dari ciptaan digarisbawahi oleh kenyataan bahwa hanya manusialah yang diciptakan Allah menurut gambar dan rupaNya sendiri (ay.27).

Hal lain yang digarisbawahi dalam perikop ini ialah bahwa Tuhan menciptakan manusia (pria dan wanita) secara bersama-sama. Penciptaan manusia secara bersama-sama itu dinyatakan oleh kata adam. Dalam bahasa Ibrani, adam secara umum berarti "kemanusiaan". Dalam Kej.1:26, kata yang digunakan adalah adam; karena itu kalimat tersebut dapat diterjemahkan menjadi seperti berikut: "Allah menciptakan kemanusiaan menurut gambarNya, Ia menciptakan laki-laki dan perempuan". Dengan demikian, manusia (adam) bukan makhluk ciptaan yang berjenis laki-laki saja, melainkan makhluk yang terdiri dari laki-laki dan perempuan. Laki-laki dan perempuan bersama-sama membentuk kemanusiaan. Dengan itu penulis ingin menegaskan bahwa manusia (pria dan wanita itu) bukan saja karya luhur Allah, tetapi juga sebagai ciptaan dan bentukan Allah, manusia itu diciptakan secara bersama-sama. ${ }^{3}$ Selanjutnya penulis Kitab ini juga menunjukkan bahwa

1 Bdk. Casti Connubii, a. 5. Casti Connubii adalah Ensiklik Paus Pius XI yang berbicara tentang Kesucian Perkawinan. Ensiklik ini diumumkan secara resmi tanggal 31 Desember 1930.

2 Benyamin Yosef Bria, Pastoral Perkawinan Gereja Katolik Menurut Kitab Hukum Kanonik 1983 Kajian dan Penerapannya, (Yogyakarta: Yayasan Pustaka Nusatama, 2007), hlm. 15.

3 Bergant, D. - Karris, R. J., Tafsir Alkitab Perjanjian Lama, (Yogyakarta: Kanisius, 2002), hlm. 36. 
Tuhan memberkati pria dan wanita itu (ay.28). Dengan cara itu tampaknya penulis mau mengungkapkan pandangannya bahwa Tuhan "menikahkan" mereka (pria dan wanita itu). Karena itu, perkawinan dalam terang perikop Kitab Kejadian ini adalah karya agung Allah, persatuan antara seorang pria dan seorang wanita yang terjadi karena "pemberkatan" yang dilakukan oleh Allah sendiri.

\subsection{Manusia: Ciptaan Allah Yang Sama Martabat (Kej.2:18-24)}

Perikop Kitab Kejadian ini langsung dibuka dengan alasan, mengapa Tuhan menciptakan wanita (atau penolong menurut ayat 18). Dan alasan yang diberikan oleh Tuhan untuk menciptakan wanita adalah "tidak baik kalau manusia itu seorang diri saja". Maksud penulis dengan kata-kata: "tidak baik kalau manusia itu seorang diri saja" adalah untuk mempertanggungjawabkan hubungan perkawinan sebagaimana ditunjukkan pada ayat 24 .

Penulis menempatkan hubungan itu dan menampilkan wanita dari perspektif abad X SM. Pada abad itu, kedudukan seorang wanita adalah untuk menolong suaminya. Dalam Perjanjian Lama "penolong" berarti seseorang yang memberi dukungan atau kekuatan, seseorang yang memungkinkan orang lain mencapai tujuannya. Cerita dari perikop ini bukan mengenai hakikat wanita, melainkan mengenai martabat wanita dalam lembaga perkawinan. Wanita dimaksudkan untuk menjadi tempat di mana laki-laki memperoleh dukungan dan kekuatan. ${ }^{4}$ Walaupun manusia dan binatang sama-sama makhluk hidup, rupanya binatang tidak bisa menjadi "penolong" yang sepadan. Lalu Tuhan menciptakan wanita (penolong itu) dengan mengambil rusuk dari laki-laki (ay.21-22). Wanita itu dinamai per-empu-an (isha=perempuan) karena ia diambil dari empu (ish=laki-laki). Melalui peristiwa ini penulis menunjukkan pandangannya bahwa manusia pria dan wanita itu tidak hanya berasal dari Tuhan pencipta yang sama, tetapi juga berasal dari materi atau bahan yang sama. ${ }^{5}$

Seturut perikop Kej.2:18-24 ini, penulis juga menunjukkan bahwa Tuhan menciptakan perempuan itu dengan terlebih dahulu membuat manusia (laki-laki itu) "tidur nyenyak". Peristiwa penciptaan wanita dari rusuk pria (yang terjadi tanpa disaksikan oleh siapapun) mengandung dua arti. Pertama: Karya penciptaan manusia oleh Allah tetap merupakan suatu misteri ilahi. Kuasa Allah tidak sanggup dipahami sepenuhnya oleh manusia. Walaupun manusia diciptakan oleh Allah, manusia tetap manusia dan Allah tetap Allah. Sebagai ciptaan Allah, manusia hanya membawa hakikat ilahi. ${ }^{6}$ Kedua: Peristiwa penciptaan dari rusuk pria ini ingin menegaskan bahwa perempuan bukanlah sembarang makhluk. Artinya, bukan karena wanita diciptakan dari tulang rusuk pria, maka dia dipandang lebih rendah dari pria. Tetapi justru sebaliknya dengan itu dia sama dengan pria yang darinya dia berasal. Wanita itu sama dengan pria, dia sederajat dengan pria, dia semartabat dengan pria, karena dia diciptakan dengan materi atau bahan dari manusia. Jadi penciptaan wanita dari tulang rusuk pria sesungguhnya mau menegaskan bahwa pria dan wanita adalah ciptaan Allah yang memiliki martabat yang sama. ${ }^{7}$

Selanjutnya penulis melaporkan bahwa Tuhan 'membawa" perempuan itu kepada manusia (laki-laki). Tuhan memperkenankan perempuan itu hidup bersama dengan laki-laki yang darinya ia berasal. Tindakan Tuhan ini mengandung arti bahwa Tuhan menikahkan mereka. Karena itu manusia itu menyambutnya dan berkata: "Inilah dia, tulang dari tulangku, dan daging dari dagingku" (ay.23). Dan ayat 24 mengakhiri dengan kata-kata: "Sebab itu seorang laki-laki akan meninggalkan ayahnya dan ibunya dan bersatu dengan

4 Ibid. hlm. 38 .

5 Ibid.

6 Bdk. http/www.gliscritti.it/approf/areopago/costacur.htm: Il Matrimonio nella Sacra Scrittura (Gen 2, Os 2 e Ct) (tpfs*) yang ditulis oleh Bruna Costacurta, yang diakses 15/8/2019.

7 Bdk. Loc. Cit. 
isterinya, sehingga keduanya menjadi satu daging". Manusia itu dipisahkan dari ayah dan ibunya dan mempersatukan diri dengan istrinya dan keduanya menjadi satu daging. Inilah perkawinan yang sesungguhnya, suatu pengintegrasian kemanusiaan. Dengan demikian, perkawinan dalam terang perikop Kej. 2:18-24 adalah persatuan yang utuh (seluruh kemanusiaan manusia) antara seorang pria dan seorang wanita, yang diciptakan oleh Allah sendiri.

\section{Perkawinan: Simbol Perjanjian Kesetiaan Tuhan dan UmatNya}

\subsection{Perkawinan Hosea dan Gomer: Simbol Kesetiaan Allah dan Ketidaksetiaan Israel (Hos. 1-3)}

Hosea bab 1-3 berbicara tentang relasi kesetiaan dan ketidaksetiaan antara Yahweh dengan Israel. Relasi antara Yahweh-Allah Israel dengan Israel-Umat pilihan Allah adalah relasi yang diwarnai oleh setia dan tidak setia. Yahweh adalah Allah yang setia, sedangkan Israel adalah umat yang tidak setia terhadap janji Allah. Ketidaksetiaan Israel menyata dalam tindakan menyembah dewa-dewa buatan sendiri yang bukan Tuhan. Hal itu dilakukan oleh pemimpin-pemimpin Israel, baik pemimpin agama maupun sipil (lih.4:4-11;5:1-3). Tindakan yang dilakukan Israel di hadapan Yahweh Allahnya itu disebut sebagai persundalan atau suatu bentuk pelacuran. Kendati Israel (melalui tingkah lakunya) menjadikan dirinya pelacur, Yahweh tetap mau memperbaharui perjanjianNya dengan Israel-pelacur itu, karena perjanjian Yahweh dengan Israel adalah perjanjian kesetiaan. ${ }^{8}$

Karena Yahweh adalah Allah yang setia, maka Yahweh memerintahkan Hosea untuk mengawini seorang wanita pelacur dan menjadikan wanita itu sebagai isterinya. Wanita itu adalah Gomer. Komando atau perintah Tuhan ini melambangkan dinamika umat Israel yang tidak setia kepada Allah dan yang sudah berbalik kepada allah-allah lain. Perkawinan yang terjadi antara Hosea dan Gomer ini, di satu sisi melukiskan kesetiaan Allah kepada Israel, di sisi lain menunjukkan ketidaksetiaan rohani Israel kepada Yahweh-Allah mereka. Di sini perkawinan digunakan sebagai simbol, karena perjanjian kesetiaan antara Yahweh dengan Israel, telah diselewengkan oleh Israel. Kendati Israel bersundal dan tidak setia, Yahweh tetap teguh setia pada perjanjianNya dengan Israel. ${ }^{9}$

Perkawinan menurut Hosea adalah perjanjian kesetiaan antara Yahweh - Allah Israel, dengan Israel - umat kepilihan Allah. Walaupun Israel tidak setia dengan melacurkan dirinya, Yahweh tetap berpegang pada kesetiaanNya. Kesetiaan Yahweh untuk tetap mau menikah dan memperbaharui pernikahannya dengan Israel yang sudah bersundal memiliki landasan dalam perjanjianNya dengan Israel; dan perjanjian Yahweh dengan Israel adalah perjanjian kesetiaan.

\subsection{Perceraian dan Perkawinan Dengan Wanita Asing: Ketidaksetiaan Israel Terhadap Janji Allah (Mal. 2:10-16)}

Masyarakat bangsa Yahudi memandang keluarga sebagai sebuah tempat di mana identitas keagamaan dan kebangsaan dipelihara. Mengenai perkawinan, orang Yahudi mengakui bahwa dengan perkawinan, seseorang memperoleh jaminan perlindungan, kehidupan, kesejahteraan dan keselamatan. Selain itu, dengan perkawinan seseorang mendapatkan kepastian bahwa dia menyandang sebuah martabat, karena perkawinan dilaksanakan dengan dilandasi oleh hal-hal yang mewajibkan. Karena itu, seorang suami yang menceraikan istrinya dengan alasan apapun, dia sesungguhnya melakukan tindakan

8 Bdk.Ibid. hlm. 630.

9 Bdk. Ibid. 
ketidakadilan. Perceraian yang dilakukan oleh seorang suami terhadap istrinya adalah suatu bentuk pengkhianatan terhadap janji Allah, dan dengan itu seseorang menentang Allah. ${ }^{10}$

Perceraian dipandang sebagai tindakan pengkhianatan terhadap Allah dan menentang Allah, karena perkawinan bagi orang Yahudi dipandang sebagai perjanjian antara Allah dengan umatNya (Yahweh dengan Israel). Mengenai perkawinan, orang Yahudi mengakui bahwa perkawinan itu hanya terjadi antara mereka saja. Seorang pria Yahudi berhak menikahi seorang wanita Yahudi, demikian pula sebaliknya. Artinya ada larangan bagi mereka untuk menikah dengan orang bukan Yahudi, atau orang di luar bangsa Yahudi. ${ }^{11}$ Yang terjadi dalam Maleakhi 2:10-16 adalah pengkhianatan Yehuda terhadap Yahweh-Allah Israel. Ada dua bentuk pengkhianatan yang dilakukan oleh Yehuda terhadap Yahweh yang sekaligus merupakan perwujudan ketidaktaatan dan ketidaksetiaan Israel terhadap janji Allah. Pertama ialah para suami Israel menceraikan istri-istri mereka yang adalah wanita-wanita Ibrani. Kedua: Para suami Ibrani yang setelah menceraikan istri-istri mereka yang adalah orang Ibrani, lalu menikahi para perempuan bukan Yahudi (wanita-wanita kafir). ${ }^{12}$

Menurut aturan adat istiadat Yahudi, orang Yahudi yang menceraikan istrinya dengan alasan apa saja, dia melakukan tindakan ketidakadilan terhadap sesama dan Tuhan, dia menolak Allah, dia menentang janji Allah. Perceraian itu menentang janji Allah karena perkawinan merupakan simbol perjanjian antara Yahweh dengan Israel (antara Tuhan dengan umatNya). Perceraian adalah satu bentuk ketidaktaatan Israel terhadap janji Allah. Perceraian adalah ungkapan ketidaksetiaan Israel terhadap Allah. Selain itu, orang Yahudi (secara khusus suami-suami Ibrani) yang menikahi wanita-wanita asing (setelah menceraikan istriistri mereka) juga adalah satu bentuk pengkhianatan dan ketidaktaatan terhadap janji Allah. Hukum perkawinan Yahudi menghendaki pria Yahudi menikahi wanita Yahudi saja. Hukum itu juga merupakan bentuk perjanjian antara Yahweh dan Israel. Tetapi yang terjadi adalah para pria Yahudi menikahi para perempuan asing, wanita kafir (bukan Yahudi). Perkawinan yang pantas sebenarnya hanya terjadi antara orang-orang dari satu bangsa yang sama (Yahudi) dan satu keyakinan serta satu Allah yang sama (Yahweh). Dan ini adalah simbol untuk perkawinan antara Tuhan dengan umatNya. Perkawinan yang terjadi antara laki-laki Yahudi dengan para perempuan kafir merupakan bentuk ketidaksetiaan Israel terhadap janji Allah.

Dengan demikian, hakikat perkawinan menurut Maleakhi 2:10-16 adalah perjanjian kesetiaan antara Yahweh-Allah Israel, dengan Israel-umat kepilihan Allah. Kendati Allah setia pada janjiNya, namun Israel mengkhianati perjanjiannya dengan Allah melalui tindakan perceraian dan mempraktekkan perkawinan dengan wanita-wanita bukan Yahudi.

\subsection{Perkawinan: Simbol Persekutuan Kristus dan Gereja (Ef.5:22-33)}

Perikop Efesus 5:21-32 melukiskan relasi antara Kristus dan Gereja sebagai relasi antara kepala dan tubuh. Kristus adalah kepala Gereja, dan Gereja adalah tubuh Kristus. Sebagai kepala Gereja, Kristus adalah penyelamat atas tubuh. Hubungan antara Kristus dan Gereja ini oleh Paulus disebut sebagai suatu rahasia. Rahasia ini besar, tetapi yang aku maksudkan ialah hubungan antara Kristus dan jemaat (Ef.5:32). Dengan ini Paulus menegaskan bahwa orang-orang kristen adalah bagian-bagian yang hidup dari Gereja.

10 Bdk. Materi Kuliah Bruno Ognibeni, Il Matrimonio Nell'antico Testamento, (Istituto Giovanni Paolo II, L'anno Academico 2010-2011).

11 Bdk. Ibid.

12 Bdk. Bergant, D. - Karris, R. J., Tafsir Alkitab Perjanjian Lama, hlm. 734-735. 
Sebagai bagian yang hidup dari Gereja, Kristus telah mengasihi Gereja dengan menyerahkan diriNya melalui hidup, wafat dan kebangkitanNya. Cinta Kristus kepada Gereja adalah cinta yang utuh, yang mengorbankan diri seluruhnya demi keselamatan GerejaNya. ${ }^{13}$

Dengan berlandaskan pada cinta Kristus kepada Gereja, relasi antara Kristus dan Gereja ditawarkan sebagai relasi model bagi hubungan yang dibangun antara suami dan istri. Suami dan istri kristen sebagai bagian dari Gereja menerima rahmat keselamatan dari Kristus, kepala dan penyelamat Gereja. Atas alasan itu, maka relasi suami-istri harus mengikuti relasi Kristus dan Gereja. Seperti Kristus telah mengasihi Gereja, demikianlah suami dan istri harus saling mengasihi. Kasih yang harus dibangun oleh suami - istri dalam perkawinan dan hidup berkeluarga adalah kasih seperti yang telah ditunjukkan Kristus kepada GerejaNya (umatNya), yakni kasih yang mengorbankan diri seutuhnya bagi keselamatan sesama. Kasih Kristus kepada Gereja adalah dasar bangunan hidup suami istri. Gereja di hadapan Kristus adalah seperti seorang istri di hadapan suami. Suami-istri kristen adalah pengantin wanita di hadapan Kristus - Sang mempelai pria. ${ }^{14}$

Dengan demikian, perkawinan antara seorang pria dan seorang wanita menurut Surat Rasul Paulus kepada Umat Efesus ini adalah simbol persekutuan atau perkawinan antara Kristus dengan jemaat. Seorang pria yang menikah dengan seorang wanita dan seorang wanita yang menikah dengan seorang pria adalah simbol perkawinan antara pria dan wanita sebagai anggota Gereja - Tubuh Kristus dengan Kristus Kepala Gereja - Sang Mempelai Pria. Perkawinan antara pria dan wanita adalah peristiwa kelihatan yang berbicara tentang partisipasi dan keterlibatan Tuhan yang tidak kelihatan. Dalam arti ini ditemukan makna dari sakramentalitas perkawinan katolik, yakni sebagai tanda kehadiran dan keselamatan yang nyata dari Tuhan dalam Kristus pada diri pasangan suami istri. ${ }^{15}$

\section{Perkawinan: Persekutuan Yang Tidak Terceraikan (Mrk.10: 1-12 dan Mat.19: 1-12)}

Dalam Kitab Suci, teks injil Markus 10:1-12 dan Matius 19:1-12 memiliki topik bacaan yang sama, yakni perihal perceraian. Topik tentang perceraian ini dikisahkan oleh dua penginjil ketika Yesus sedang melaksanakan karya pewartaan dan pengajaranNya kepada orang banyak di daerah Yudea di seberang sungai Yordan. Dikatakan bahwa Yesus didatangi oleh orang-orang Farisi, dan dengan maksud untuk mencobaiNya, mereka bertanya kepada Yesus tentang boleh tidaknya perceraian dalam perkawinan. Pertanyaan utama mereka ialah apakah seorang suami boleh menceraikan istrinya dengan alasan apa saja. Menanggapi pertanyaan mereka, Yesus bertanya balik kepada mereka tentang apa yang ditulis oleh Musa dalam Perjanjian Lama perihal perceraian. Mereka katakan bahwa Musa mengizinkan orang untuk menceraikan istrinya dengan membuat surat cerai. Menanggapi jawaban mereka, Yesus berkata: Apa yang dibuat oleh Musa itu sesungguhnya karena ketegaran hati manusia; sebab sejak awal dunia Tuhan telah menjadikan laki-laki dan perempuan, dan Tuhan sendiri telah mempersatukan mereka. Apa yang Tuhan persatukan, tidak ada kuasa manusiawi manapun yang bisa memisahkannya.

Inti dari jawaban Yesus berkaitan dengan perkara yang diangkat oleh orang-orang Farisi di sini adalah bahwa perceraian dalam perkawinan itu tidak diiizinkan. Kalau pada

13 Bdk. Al. Purwa Hadiwardoyo, Perkawinan Dalam Tradisi Katolik, (Yogyakarta: Kanisius, 1988), hlm. 24. 349.

14 Bdk. Bergant, D. - Karris, R. J., Tafsir Alkitab Perjanjian Baru, (Yogyakarta: Kanisius 2002), hlm.

15 Bdk. Loc. Cit. 
masa Musa perceraian itu terjadi atau ada, hal itu bukan terjadi karena dikehendaki, tetapi karena terpaksa. Maksudnya, terpaksa terjadi karena ketegaran hati manusia. Lalu mengapa perceraian tidak diizinkan dalam perkawinan, tegas Yesus? Alasannya ialah karena Tuhan sendiri yang mempersatukan pria dan wanita dalam perkawinan. Perceraian juga tidak diizinkan oleh Yesus, karena pria dan wanita ciptaan Allah itu memiliki martabat yang sama. Yesus mendasari ajaranNya dengan mengangkat apa yang dikatakan dalam Kitab Kejadian 1:27 ialah bahwa dalam rencana Allah yang asli, penciptaan perkawinan bersifat tidak terceraikan, dan tidak ada satu instansi manusiawi pun yang bisa memutuskan persatuan perkawinan. Dalam penciptaan sendiri, pria dan wanita adalah satu. ${ }^{16}$

Atas dasar alasan dimaksud, maka kedua perikop injil ini sesungguhnya berbicara tentang hakekat perkawinan kristiani. Perkawinan dalam terang pandangan Yesus adalah persekutuan yang diciptakan oleh Allah sendiri. Tuhan sendirilah yang menciptakan pria dan wanita, dan Tuhan sendiri pula yang mempersatukan pria dan wanita seturut kehendakNya. Mereka bukan lagi dua, melainkan satu. Karena itu, apa yang telah dipersatukan Allah, tidak boleh diceraikan manusia. Perkawinan merupakan suatu persekutuan yang memiliki ciri tidak terceraikan.

\section{Perkawinan: Karya Agung Allah yang Menuntut Keterlibatan Manusia}

Para penulis Perjanjian Lama percaya bahwa kasih perkawinan merupakan bagian dari maksud Allah menciptakan manusia. Penciptaan manusia bukanlah suatu peristiwa aksidental, juga bukan merupakan suatu peristiwa penemuan manusia. Tetapi rencana baik Allah, bagian dari cara Allah menciptakan dunia. ${ }^{17}$

Ide ini dapat ditemukan dengan jelas dalam kisah-kisah penciptaan dalam Kitab Kejadian, seperti terungkap melalui kata-kata berikut: "Maka Allah menciptakan manusia itu menurut gambarNya, menurut gambar Allah diciptakanNya dia; laki-laki dan perempuan diciptakanNya mereka" (Kej.1:27). Lalu berkatalah manusia itu: "Inilah dia, tulang dari tulangku dan daging dari dagingku. Ia akan dinamai perempuan, sebab ia diambil dari lakilaki. Sebab itu seorang laki-laki akan meninggalkan ayah dan ibunya dan bersatu dengan istrinya, sehingga keduanya menjadi satu daging" (Kej.2:23-24).

Penulis kisah ini memandang bahwa perkawinan itu penting, sehingga ia menempatkannya tepat di tengah kisah penciptaan. Baginya dan bagi masyarakat Yahudi kuno lainnya, perkawinan merupakan bagian pokok dari kemanusiaan dan juga merupakan bagian sentral dari maksud Allah bagi hidup manusia. Penulis kisah juga berpendapat bahwa kasih perkawinan itu bersifat kreatif yang mendukung kepada datangnya generasi baru melalui peristiwa kelahiran. Atas alasan itu maka Kitab Suci mengatakan bahwa laki-laki dan perempuan yang telah meninggalkan ayah dan ibunya itu mereka hidup dalam persatuan, menjadi satu daging. Persatuan yang dimaksudkan di sini tidak hanya sekedar mengungkapkan tentang suasana romantis kedua manusia pria dan wanita, tetapi lebih dari itu mau menyatakan dengan tegas tentang suatu relasi khusus yang dibangun antara pria dan wanita sebagai suami istri, yakni persekutuan seksual yang terbuka kepada kelahiran manusia baru. Karena itu dalam kaca mata dan pemahaman penulis, kasih perkawinan yang dimaksud

16 Op. Cit. hlm. 62.

17 Simon \& Christoper Danes, P. Hardono Hadi, Masalah-Masalah Moral Sosial Aktual Dalam Perspektif Iman Kristen, (Yogyakarta: Kanisius, 2000), hlm. 49. 
adalah perkawinan yang berciri prokreatif, yang memungkinkan datangnya manusia baru melalui tindakan persekutuan seksual suami istri. ${ }^{18}$

Dengan landasan pikiran ini, dapat ditegaskan bahwa perkawinan itu adalah sesuatu yang suci. Kesucian perkawinan di sini memiliki dasar di dalam Allah. Bahwa Allah sendirilah yang menciptakan perkawinan itu. Karena Allah adalah suci, maka perkawinan itu juga suci. ${ }^{19}$ Dan melalui perkawinan, Allah ingin agar manusia hidup, bertumbuh dan melanjutkan hidup untuk generasi sesudahnya. Dengan ini mau dinyatakan bahwa perkawinan yang dibangun oleh Allah itu, juga menuntut keterlibatan penuh dari pihak manusia. Allah menciptakan lembaga perkawinan, hukum-hukum, tujuan dan ciri-cirinya; manusia mengawali terbentuknya dengan persetujuan kehendak bebasnya. ${ }^{20}$ Melalui menggunakan kehendak bebasnya itu manusia harus terlibat aktif dalam karya yang dikehendaki Allah Pencipta baginya. Perkawinan dengan demikian tidak hanya merupakan bagian dari rencana Allah menciptakan manusia, tetapi serentak menjadi medan yang dalamnya manusia terlibat secara kreatif mengembangkan diri dan hidupnya. Perkawinan dalam arti ini adalah karunia agung Allah yang menunut partisipasi dan keterlibatan manusia.

Sebagai karya agung Allah, perkawinan dilindungi dalam hukum Perjanjian Lama. Dalam dekalog yang diberikan Allah kepada Musa di Sinai misalnya, ada hukum yang melarang perzinahan (jangan berzinah). Hukuman bagi orang yang melakukan perzinahan di masa Perjanjian Lama adalah kematian. Kitab Imamat 20:10 menyatakan bahwa seorang lakilaki yang berzinah dengan istri sesamanya, maka keduanya akan dihukum mati. Setiap tindakan yang mencederai hakekat perkawinan, seperti perzinahan dan penyembahan berhala, diyakini sebagai tindakan yang melanggar keadilan. Praktek ketidakadilan itu dipandang sebagai tindakan menentang Allah. Tindakan melanggar inti hakekat perkawinan itu adalah bentuk ketidaksetiaan manusia terhadap Allah. ${ }^{21}$

Dalam Perjanjian Baru, Yesus dan Rasul Paulus juga menegaskan tentang pentingnya menjaga dan mempertahankan hakekat perkawinan sebagai karya Allah yang suci. Yesus dalam pengajaranNya menegaskan bahwa perceraian tidak ada dalam perkawinan, karena yang mempersatukan pria dan wanita dalam perkawinan adalah Tuhan sendiri. Kalau dalam Perjanjian Lama ditemukan ada praktek perceraian, itu adalah karena ketegaran hati manusia dan terjadi karena terpaksa, bukan karena hukum menghendaki (Mat.19:8). Dan Paulus menggarisbawahi tentang partisipasi Tuhan dalam perkawinan dengan menyatakan bahwa perkawinan merupakan lambang persatuan Kristus dengan GerejaNya. Dalam perkawinan, Tuhan melalui Kristus hadir secara nyata melalui sakramen yang menyelamatkan umatNya. Atas dasar itu maka suami dan istri dipanggil untuk saling menghadirkan diri mereka sebagai sakramen (tanda keselamatan) satu terhadap yang lain dalam situasi apapun, termasuk dalam keadaan susah dan derita. Cinta mereka satu terhadap yang lain adalah cinta yang rela mengorbankan diri seperti yang telah ditunjukkan oleh Yesus Kristus mempelai Gereja (Ef.5:32-33).

Tema tentang kesucian perkawinan dan kejahatan perzinahan serta penyembahan berhala diangkat dalam kisah-kisah Perjanjian Lama dimaksud untuk memberi petunjuk kepada orang Yahudi tentang bagaimana mereka harus menghayati kehidupan yang baik dan benar sesuai dengan kehendak Allah. ${ }^{22}$ Demikian juga tema tentang keluhuran perkawinan sebagai persatuan antara Kristus dan Gereja serta perceraian diangkat untuk menunjukkan

18 Ibid.

19 Casti Connubi, a. 5.

20 Ibid. a. 10.

21 Bdk. Simon \& Christoper Danes, P. Hardono Hadi, hlm. 49.

22 Ibid. 
bahwa perkawinan yang merupakan karya agung Allah adalah suatu lembaga tetap tak terceraikan, dan karena itu suami istri hari demi hari dipanggil untuk selalu menumbuhkan bangunan hidup perkawinan dan keluarga mereka agar pada saatnya membuahkan kebahagiaan dan keselamatan hidup bersama, suatu cita-cita yang telah ditetapkan Allah sejak penciptaan.

\section{Penutup}

Mengapa perkawinan disebut suci atau kudus, karena perkawinan dibentuk oleh Allah, perkawinan memiliki dasar di dalam Allah yang adalah kudus. Perkawinan juga disebut kudus, karena perkawinan melukiskan relasi yang dibangun antara Tuhan dan manusia. Dalam perkawinan, Tuhan yang suci dan kudus bersekutu dengan manusia yang rapuh dan mudah jatuh dalam dosa. Perkawinan merupakan simbol perjanjian kudus antara Allah dan manusia. Perkawinan juga menjadi gambaran persekutuan cinta kasih antara Tuhan dan umatNya.

Melalui perjanjian kudus yang diikat antara Allah dan manusia itu, manusia oleh Allah dipanggil untuk hidup dan bersikap seperti Allah yang kudus dan setia. Atas dasar alasan itu, kesetiaan Tuhan dalam memperlihatkan dan mempertahankan ikatan perjanjianNya dengan manusia, bagi manusia tidak hanya sekedar inspirasi, tetapi lebih dari itu memanggil manusia dengan tegas untuk mewujudkan kesetiaannya kepada Tuhan melalui ketaatan memelihara dan menghayati isi perjanjiannya dengan Allah. Cara manusia mewujudkan isi perjanjiannya dengan Allah ialah dengan tetap hidup dalam persekutuannya dengan Allah, bukan sebaliknya menceraikan diri dari Allah, lalu melekatkan diri pada dewadewi yang bukan Allah.

Sebagai mempelai pria, Yahweh-Allah Israel menghendaki Israel pilihanNya dan Gereja umatNya setia seperti Dia. Yahweh- Allah Israel dan Kristus kepala Gereja tidak menghendaki para mempelainya memisahkan diri dariNya, bercerai dariNya, kemudian bersekutu dan bertuan pada allah-allah lain yang bukan Tuhan. Tuhan yang setia juga tidak menghendaki para suami istri yang menikah mengingkari janji setia mereka dengan memisahkan atau menceraikan diri dari pasangannya, lalu menghampiri dan kawin dengan wanita dan pria bukan pasangannya. Jika ada suami istri mengingkari janji perkawinannya, maka itu bentuk pengkhianatan dan penolakannya terhadap Tuhan dan pasangannya. Penolakan itu adalah perwujudan nyata dari ketidaksetiaannya terhadap janjinya dengan Allah.

Kesetiaan manusia terhadap perjanjiannya dengan Allah menentukan statusnya untuk mengambil bagian dalam kesucian atau kekudusan Allah. Kesetiaan merupakan landasan menuju kekudusan. Kesetiaan Tuhan terhadap perjanjian pantas menjadi dasar pijak perwujudan kesetiaan manusia dalam perjanjiannya dengan Allah. Secara khusus para suami istri yang telah mempersatukan diri mereka dalam ikatan perjanjian perkawinan, kesetiaan Yahweh terhadap Isarel dan kesetiaan Kristus terhadap Gereja adalah dasar teladan dan penunjuk arah dalam menghayati kesetiaan hidup perkawinan mereka. 


\section{Daftar Kepustakaan}

Al. Purwa Hadiwardoyo, Perkawinan Dalam Tradisi Katolik, Yogyakarta: Kanisius, 1988.

Benyamin Yosef Bria, Pastoral Perkawinan Gereja Katolik Menurut Kitab Hukum Kanonik 1983 Kajian dan Penerapannya, Yogyakarta: Yayasan Pustaka Nusatama, 2007.

Bergant, D. - Karris, R. J., Tafsir Alkitab Perjanjian Lama, Yogyakarta: Kanisius, 2002. ., Tafsir Alkitab Perjanjian Baru, Yogyakarta: Kanisius, 2002.

Bruno Ognibeni, Il Matrimonio Nell'antico Testamento - Il Materiale del Corso, Roma: Istituto Giovanni Paolo II, L’anno Academico 2010-2011.

Kitab Suci Perjanjian Lama dan Perjanjian Baru, Jakarta: Lembaga Alkitab Indonesia, 1991.

Paus Pius XI, Ensiklik Casti Connubii: 31 Desember 1930.

Simon \& Christoper Danes, P. Hardono Hadi: Masalah-Masalah Moral Sosial Aktual Dalam Perspektif Iman Kristen, Yogyakarta: Kanisius, 2000.

Internet: Http/www.gliscritti.it/approf/areopago/costacur.htm: Il Matrimonio nella Sacra Scrittura, (Gen 2, Os 2 e Ct) karya Bruna Costacurta, diakses 15 Agustus 2019. 